\title{
Rearrangements and Point Mutations of P450c21 Genes Are Distinguished by Five Restriction Endonuclease Haplotypes Identified by a New Probing Strategy in 57 Families with Congenital Adrenal Hyperplasia
}

\author{
Yves Morel, ^‡ Jean André," Beatrice Uring-Lambert, Georges Hauptmann, ${ }^{5}$ Herve Bétuel," Mario Tossi," \\ Maguelone G. Forest, " Michel David, "* Jean Bertrand, ${ }^{*}$ and Walter L. Miller \\ *Institut National de la Santé et de la Recherche Medicale U34, 69322 Lyon, Cedex 05, France; ${ }^{\ddagger}$ Department of Pediatrics, University \\ of California San Francisco, San Francisco, California 94143; ${ }^{\S}$ Laboratoire de Recherches en Immunologie, 67085 Strasbourg, France; \\ "Centre de Transfusion Sanguine, 69342 Lyon, Cedex 07, France; "Unité d'Immunogénétique, Institut Pasteur, 75724 Paris, Cedex 15, \\ France; and ${ }^{* *}$ Pediatric Clinic, Hopital Debrousse, 69322 Lyon, Cedex 05, France
}

\begin{abstract}
Congenital adrenal hyperplasia (CAH) is caused by disorders of the P450c21 B gene, which, with the P450c21 A pseudogene, lies in the HLA locus on chromosome 6 . The near identity of nucleotide sequences and endonuclease cleavage sites in these $A$ and $B$ loci makes genetic analysis of this disease difficult. We used a genomic DNA probe that detects the P450c21 genes (A pseudogene, $3.2 \mathrm{~kb}$; $B$ gene, $3.7 \mathrm{~kb}$ in Taq I digests) and the $3^{\prime}$ flanking DNA not detected with cDNA probes (A pseudogene, $2.4 \mathrm{~kb}$; B gene, $2.5 \mathrm{~kb}$ ) to examine Southern blots of genomic DNA from 68 patients and 165 unaffected family members in 57 families with CAH. Of 116 CAH-bearing chromosomes, 114 could be sorted into five easily distinguished haplotypes based on blots of DNA digested with Taq I and Bgl II. Haplotype I (76 of 116, 65.6\%) was indistinguishable from normal and therefore bore very small lesions, presumably point mutations. Haplotype II (4 of $116,3.4 \%)$ and haplotype III (8 of 116, 6.9\%) had deletions and duplications of the P450c21A pseudogene but had structurally intact P450c21 B genes presumably bearing point mutations; point mutation thus was the genetic defect in 88 of 116 chromosomes (75.9\%). Haplotypes IV and V lack the 3.7-kb Taq I band normally associated with the P450c21B gene. Haplotype IV $(13$ of $116,11.2 \%)$ retains all other bands, indicating that the $P 450$ c21 $B$ gene has undergone a gene conversion event, so that it is now also associated with a 3.2-kb band. Haplotype $\mathrm{V}$ (13 of 116, 11.2\%) lacks the 2.4-kb Taq I fragment and the 12-kb Bgl II fragments normally associated with the P450c21A pseudogene, as well as lacking the $3.7-\mathrm{kb}$ Taq I fragment, indicating deletion of $\sim 30 \mathrm{~kb}$ of DNA, resulting in a single hybrid P450c21A/B gene. Most (114 of 116, 98\%) CAH al-
\end{abstract}

Preliminary reports of these data were presented at the 29th Annual Meeting of the European Society for Pediatric Endocrinology, Zurich, Switzerland, 31 August-3 September, 1986 (1986. Pediatr. Res. 20:1200, Abstr. 132) and at the 70th Annual Meeting of the Endocrine Society, New Orleans, Louisiana, 8-11 June 1988 (1988. Endocrinology. 122:Suppl. 21, Abstr. 2).

Address reprint requests to Dr. Walter L. Miller, Room 677-S, Department of Pediatrics, University of California, San Francisco, San Francisco, CA 94143.

Received for publication 9 August 1988 and in revised form 30 September 1988.

J. Clin. Invest.

(c) The American Society for Clinical Investigation, Inc. $0021-9738 / 89 / 02 / 0527 / 10 \$ 2.00$

Volume 83, February 1989, 527-536 leles thus can easily be classified with this new probing strategy, eliminating many ambiguities resulting from probing with cDNA.

\section{Introduction}

Congenital adrenal hyperplasia $(\mathrm{CAH})^{1}$ due to deficient 21 -hydroxylase activity is an autosomal recessive disorder linked to the MHC locus on the short arm of chromosome $6(1,2)$. 21-hydroxylase activity is mediated by $\mathrm{P} 450 \mathrm{c} 21$, a microsomal cytochrome P450 enzyme (for review, see reference 3 ). Two highly homologous genes encoding P450c21, formally termed P450XXIA1 and P450XXIA2 (4) and commonly termed $\mathrm{P} 450 \mathrm{c} 21 \mathrm{~A}$ and $\mathrm{P} 450 \mathrm{c} 21 \mathrm{~B}$, are linked in tandem with $\mathrm{C} 4 \mathrm{~A}$ and $\mathrm{C} 4 \mathrm{~B}$, the genes encoding the fourth component of complement $(5,6)$. Only the P450c21 B gene is active; $\mathrm{P} 450 \mathrm{c} 21 \mathrm{~A}$ is an inactive pseudogene due to an 8-base deletion causing a frame shift plus a point mutation creating a stop codon (7-9). The order and transcriptional orientations of these genes have been established $(2,10)$. The P450c21 genes are $\sim 3.4 \mathrm{~kb}$ long and contain 10 exons $(7,8,11)$. A region of $\sim 35 \mathrm{~kb}$ excompassing a C4 gene and a P450c21 gene has been duplicated in evolution, resulting in this tandem array of $\mathrm{C} 4$ and $\mathrm{P} 450 \mathrm{c} 21$ genes in mice (12), probably cattle (13), and human beings $(5,6)$. The two human P450c21 genes have 98\% nucleotide identity (7-9), even though this duplication occurred before mammalian speciation; thus, the two loci are evolving in tandem (concerted evolution) $(14,15)$. This extremely high degree of nucleotide identity thus indicates extremely frequent crossover events, and makes genetic distinction of the loci difficult (16).

Some restriction enzymes can distinguish the two P450c21 genes in normal persons. The $\mathrm{P} 450 \mathrm{c} 21 \mathrm{~A}$ pseudogene is characterized by $3.2-\mathrm{kb}$ Taq I and $12-\mathrm{kb}$ Bgl II fragments, whereas the functional P450c21 B gene is characterized by $3.7-\mathrm{kb}$ Taq I and 11-kb Bgl II fragments. A deletion of the P450c21B gene, evidenced by an absent 3.7-kb Taq I fragment, was reported in a patient homozygous for HLA-A3, -B47, -DR7, C4A91 C4BQ0 (17). In hormonally normal individuals, including homozygotes for HLA-A1, -B8, -DR3, C4AQ0 C4B1, absence of the 3.2-kb Taq I fragment suggested deletion of the P450c21A pseudogene $(17,18)$. Deletions simultaneously affecting the P450c21 gene have been reported in selected populations hav-

1. Abbreviations used in this paper: $\mathrm{CAH}$, chronic adrenal hyperplasia; NC, nonclassical form; 17OHP, 17-hydroxyprogesterone; SV, simple virilizing form; SW, salt-wasting form. 
ing certain HLA and complement types (18-20). Schneider et al. used Taq I digests alone to report deletion of the P450c21 B gene in 10 of the 16 chromosomes from eight CAH patients who also carried a C4B null allele (20). However, two of these retained the $\mathrm{C} 4 \mathrm{~A}$ and $\mathrm{C} 4 \mathrm{~B}$ genes but lacked the 3.7-kb Taq I fragment and hence probably had gene conversions. Werkmeister et al., excluding CAH patients with HLA-A3, -B47, -DR7, C4A91 C4BQ0, reported seven deletions among 30 CAH alleles (21). Rumsby et al. (22) found the same result for 9 of $40 \mathrm{CAH}$ haplotypes.

However, patients lacking the 3.7-kb Taq I fragment who nonetheless retain the $\mathrm{P} 450 \mathrm{c} 21 \mathrm{~B}$ gene have been reported (23). This phenomenon is generally termed "gene conversion," as the structure of the P450c21B gene is apparently converted to that of the P450c21A pseudogene $(15,22-27)$. The relative frequency of gene conversion versus gene deletion in $\mathrm{CAH}$ has been highly controversial. Jospe et al. reported nine deletions and three gene conversions among 28 salt-losing $\mathrm{CAH}$ chromosomes (24). Matteson et al. reported that the apparent gene deletions seen with Taq I ( 8 out of 20 salt-losing CAH chromosomes) were inconsistent with results in four other restriction enzymes; they proposed that those apparent deletions represented gene conversions, unequal crossovers or polymorphisms, but not physical loss of the P450c21B gene (25). Higashi et al. found that 9 of $22 \mathrm{CAH}$ chromosomes lacked the 3.7-kb Taq I fragment, but that all retained at least part of the P450c21 B gene (26). In other Japanese patients, Harada et al. found 6 of 21 unrelated affected chromosomes lacking the 3.7-kb Taq I fragment, of which four were due to gene conversion; this was confirmed for one chromosome by DNA sequencing (27). By contrast, White et al. recently showed that in their patient population 13 of $15 \mathrm{CAH}$ chromosomes lacking the 3.7-kb Taq I fragment had bona fide gene deletions (28). The frequency of gene deletion versus gene conversion thus varies greatly among published studies of small series of patients.

To determine the frequency of various types of genetic defects causing $\mathrm{CAH}$, we studied 57 French families with 68 affected and 165 unaffected family members. For this study we used a new DNA probing tactic using a P450c21 genomic probe, rather than a cDNA probe. This genomic probe can distinguish the P450c21A and $B$ genes by the 3.7- and 3.2-kb Taq I fragments, as seen with a cDNA probe, and also by the $2.4-$ and $2.5-\mathrm{kb}$ fragments lying immediately downstream (3') from these; this greatly simplifies the analysis of this complex locus, and permits the assignment of 114 of 116 affected chromosomes bearing CAH to one of five DNA haplotypes. We find that $\sim 76 \%$ of chromosomes have grossly intact P450c21B genes and, hence, probably carry point mutations. Chromosomes bearing gene deletions and gene conversions were equally abundant, each $\sim 11 \%$ of chromosomes carrying $\mathrm{CAH}$.

\section{Methods}

Patients and families. $68 \mathrm{CAH}$ patients in 57 families were studied including 47 families with 1 patient, 6 families with 2 patients, and 3 families with 3 patients. As two parents themselves had $\mathrm{CAH}$, these 57 families bore a total of 116 affected chromosomes $[(2 \times 57)+2=116]$. These families were unrelated and had no known consanguinity. 17 family studies were incomplete because some members were deceased, unavailable for study, or refused study. All available family members underwent HLA-B typing.
All patients were diagnosed by elevated plasma 17-hydroxyprogesterone (170HP) and were seen at least twice per year to monitor their hormonal replacement therapy. The patients were classified as having one of the three clinical forms of CAH defined according to standard criteria (2). CAH with salt wasting (SW) was characterized by onset of hyperkalemia, hyponatremia, dehydration, shock, hyperreninemia, and extremely elevated serum concentrations of $170 \mathrm{OP}$ in the first month of life, which required treatment with both mineralocorticoids and glucocorticoids. Females had ambiguous genitalia and males had enlarged hyperpigmented genitalia. The simple virilizing form (SV) was usually diagnosed in late infancy or early childhood; females had ambiguous genitalia recognized at various ages, and males were referred for sexual precocity. Heights and bone ages were markedly advanced, and plasma renin activities were elevated in all SV patients. The nonclassical form (NC) was characterized in girls by normal external genitalia, precocious adrenarche, and elevated 17OHP responses to ACTH but no clinical or chemical signs of salt loss. Among our 57 CAH families, 42 had SW, 11 had SV, 4 had NC, and 2 parents also had NC.

HLA and complement typing. Leukocyte HLA typing was done by the stage microlymphotoxicity test $(29,30)$. Complement $\mathrm{C} 2$, Bf, and C4 types were determined as described (31), and $\mathrm{C} 4$ variants were identified by high-voltage agarose gel electrophoresis with subsequent immunofixation and hemolytic overlay or immunoblotting using anti-C4A and anti-C4B MAb (gifts from Dr. G. O'Neill, American Red Cross, Miami, FL) (32).

DNA blotting studies. Human leukocyte DNA was digested with restriction endonucleases, electrophoresed in 0.7 or $1.0 \%$ agarose gels, and analyzed by Southern blotting to nylon membranes by standard procedures. Blots were probed with a 2.7-kb Eco RI fragment of the murine P450c21A gene (12) under low-stringency conditions and with human P450c21 cDNA (25) under high-stringency conditions. Highstringency conditions were $2 \times \mathrm{SSC}$ (SSC is $0.15 \mathrm{M} \mathrm{NaCl}, 0.015 \mathrm{M} \mathrm{Na}$ citrate), $50 \%$ deionized formamide, $50 \mathrm{mM}$ Tris- $\mathrm{HCl}(\mathrm{pH} 7.5), 0.02 \%$ wt/vol each of polyvinylpyrrolidone, Ficoll, and BSA, $1 \% \mathrm{NaDodSO}_{4}$, and $100 \mu \mathrm{g} / \mathrm{ml}$ denatured salmon sperm DNA (Sigma Chemical Co., St. Louis, MO). Low stringency conditions substituted $6 \times$ SSC and $40 \%$ deionized formamide in the above recipe. Overnight prehybridization and 24 -h hybridization were at $42^{\circ} \mathrm{C}$. After hybridization, nylon membranes were washed twice with $2 \times \mathrm{SSC}$ at $22^{\circ} \mathrm{C}$, then three times with $0.1 \times \mathrm{SSC}, 1 \% \mathrm{NaDodSO}_{4}$ (high stringency) or $2 \times \mathrm{SSC} 1 \% \mathrm{Na}-$ $\mathrm{DodSO}_{4}$ (low stringency) for $30 \mathrm{~min}$ at $65^{\circ} \mathrm{C}$. After a final wash at $22^{\circ} \mathrm{C}$, the wet membranes were exposed to Kodak XAR-5 films for $5-10 \mathrm{~d}$ at $-70^{\circ} \mathrm{C}$ with intensifying screens. The validity of the data obtained with the mouse genomic DNA probe was confirmed by reprobing all Taq I digests with the human P450c21 cDNA (see examples in Fig. 3, below). Some Taq I blots were also hybridized with a 476-bp Bam HI-Kpn I restriction fragment from the full-length C4 cDNA clone, pAT-A (33) corresponding at the $5^{\prime} \mathrm{C} 4$ region, using high-stringency conditions.

\section{Results}

Study population. All affected individuals, obligate heterozygotes, and other family members underwent HLA-B typing. The distribution of HLA-B alleles among 78 unaffected chromosomes from phenotypically normal family members was the same as among a published normal French population (Table I, columns $a$ and $b$ ). By contrast, the distribution of HLA-B alleles among affected chromosomes differed from our unaffected chromosomes. HLA-B8 was found less frequently and HLA-B14 and -B47 were found more commonly on chromosomes bearing CAH (Table I). The incidence of HLA-B47 in our patient population is lower than in some other studies $(34,35)$.

DNA haplotyping procedure. A DNA haplotype of Taq I and Bgl II fragments was determined for 116 chromosomes 
Table I. Allele Frequencies (Percentages) at the HLA-B Locus among the Chromosomes Studied

\begin{tabular}{|c|c|c|c|c|c|c|c|}
\hline \multirow[b]{2}{*}{ HLA-B alleles } & \multirow[b]{2}{*}{$\begin{array}{c}\text { General population* } \\
(n=124) \\
(a)\end{array}$} & \multirow[b]{2}{*}{$\begin{array}{l}\text { Unaffected haplotypes } \\
\qquad \begin{array}{c}(n=78) \\
(b)\end{array}\end{array}$} & \multicolumn{4}{|c|}{ Affected haplotypes } & \multirow[b]{2}{*}{ Chi square test } \\
\hline & & & $\begin{array}{c}\text { Total } \\
(n=110) \\
(c)\end{array}$ & $\begin{array}{l}\mathrm{SW} \\
(n=77) \\
(d)\end{array}$ & $\begin{array}{c}\mathrm{SV} \\
(n=22) \\
(e)\end{array}$ & $\begin{array}{c}\mathrm{NC} \\
n=11 \\
(f)\end{array}$ & \\
\hline $5(w 51-w 52)$ & 8.0 & 7.7 & 10.0 & 5.1 & 0.0 & - & \\
\hline 7 & 5.8 & 10.2 & 6.4 & 6.5 & 9.1 & - & \\
\hline 8 & 8.0 & 9.0 & 0.9 & 1.3 & 0.0 & - & ${ }^{\ddagger} b$ vs. $c,{ }^{\S} b$ vs. $d$ \\
\hline $12(w 44-w 45)$ & 16.9 & 17.9 & 9.1 & 10.4 & 9.1 & - & \\
\hline 14 & 3.4 & 2.6 & 9.1 & 3.9 & 13.6 & 36.3 & ${ }^{\S} b$ vs. $e,^{\ddagger} b$ vs. $f$ \\
\hline 15 (w62-w63) & 6.8 & 5.1 & 9.1 & 11.7 & 0.0 & - & \\
\hline 18 & 5.8 & 6.4 & 3.6 & 3.9 & 4.1 & - & \\
\hline 27 & 4.1 & 5.1 & 5.5 & 5.2 & 4.5 & - & \\
\hline 35 & 8.4 & 14.1 & 9.1 & 10.4 & 4.5 & - & \\
\hline 40 (w60-w61) & 7.5 & 2.6 & 5.5 & 5.1 & 0.0 & - & \\
\hline 47 & 1.2 & 0.0 & 7.3 & 9.1 & 4.5 & - & $" b$ vs. $c$, $" b$ vs. $d$ \\
\hline Other HLA-B alleles & 24.1 & 19.3 & 24.4 & 27.4 & 50.6 & - & \\
\hline
\end{tabular}

$n$, number of haplotypes studied; * data from Betuel et al. (29). Genotype frequencies $(g)$ are calculated from the phenotype frequencies $(p)$ according to the formula $g=1-\sqrt{1-p}$. Significance was tested with the Chi square test. $P$ values are: ${ }^{\ddagger}<0.01,{ }^{\S}<0.05$, and $"<0.025$.

bearing $\mathrm{CAH}$ and 84 normal chromosomes from family members (including the 78 chromosomes in Table I). Taq I digests of DNA were probed with a murine $2.7-\mathrm{kb}$ Eco RI genomic DNA fragment extending over 800 bases downstream from the $3^{\prime}$ Taq I site of the P450c21 genes (12). This probe detects the 3.2- and 3.7-kb fragments characteristic of the P450c21 A and B genes, respectively, and also detects the adjacent downstream Taq I fragments that cannot be detected by the cDNA probe (Fig. 1). For the P450c21A pseudogene, the next Taq I fragment downstream from the $3.2-\mathrm{kb}$ fragment is 2.4-kb. For the P450c21B gene, the next Taq I fragment

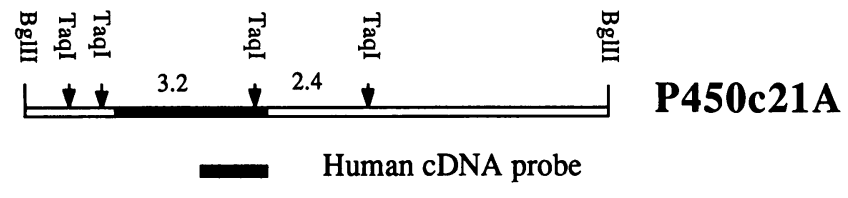

Mouse genomic probe

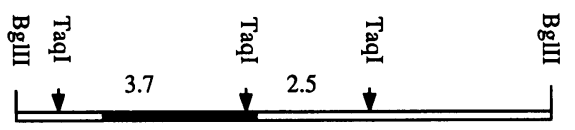

P450c21B

\begin{tabular}{lllllll}
0 & 2 & 4 & 6 & 8 & 10 & 12 \\
\hline
\end{tabular}

Figure 1. Diagram of the P450c21 genes (derived from references 4, 6, and 24). The 12-kb Bgl II DNA fragment bearing the P450c21A pseudogene is shown above and the $11-\mathrm{kb} \mathrm{Bgl}$ II fragment bearing the functional P450c21B gene is shown below. The P450c21 genes, spanning $\sim 3.5 \mathrm{~kb}$, are shown in black. The locations of the Taq I recognition sites are indicated by solid arrowheads pointing downward. The 3.2- and 3.7-kb Taq I fragments bearing the P450c21 A and B genes, respectively, are indicated, along with the downstream 2.4- and 2.5-kb fragments. The regions of the DNA hybridizing to the probes used in this study are indicated between the two gene diagrams. The scale below indicates distance in kilobases. downstream from the $3.7-\mathrm{kb}$ fragment is $2.5 \mathrm{~kb}$. The $3^{\prime}$ flanking DNA as well as the genes themselves thus can be distinguished. Bgl II digested DNA yields fragments of $12 \mathrm{~kb}$ bearing the entire $\mathrm{P} 450 \mathrm{c} 21 \mathrm{~A}$ pseudogene, and $11 \mathrm{~kb}$, bearing the $\mathrm{P} 450 \mathrm{c} 21 \mathrm{~B}$ gene. There is no difference in the $\mathrm{Bgl}$ II pattern seen on blots probed with the mouse genomic DNA probe or the human cDNA probe, as the $3^{\prime} \mathrm{Bgl}$ II restriction site lies far downstream from both probes (Fig. 1).

Five different restriction pattern haplotypes were identified among the 116 affected CAH chromosomes (Fig. 2). In haplotypes II to $\mathrm{V}$, lane $a$ shows a typical patient homozygous for the pattern and therefore represents the restriction pattern haplotype. By contrast, lane $b$ shows a compound heterozygous patient carrying one chromosome of the indicated haplotype and one chromosome with haplotype I.

CAH haplotype I. Haplotype I has 3.7- and 3.2-kb Taq I bands of equal intensity, 2.5- and 2.4-kb Taq I bands of equal intensity, and 12- and $11-\mathrm{kb} \mathrm{Bgl}$ II bands of equal intensity (Fig. 2). This haplotype represents $65.6 \%$ (76 of 116 ) of affected chromosomes (Table II). It does not differ from the normal pattern, and hence indicates very small changes in the affected genes, presumably point mutations.

CAH haplotype II. Haplotype II lacks the 3.2- and 2.4-kb Taq I bands and the $12 \mathrm{~kb} \mathrm{Bgl} \mathrm{II} \mathrm{band} \mathrm{indicating} \mathrm{deletion} \mathrm{of}$ the P450c21A pseudogene. This haplotype represents only $3.4 \%$ ( 4 of 116) of the affected chromosomes. A patient heterozygous for this haplotype has decreased autoradiographic intensity of the 3.2- and 2.5-kb Taq I bands compared with the 3.7- and 2.5-kb Taq I bands, respectively, and similarly has a decreased 12-kb Bgl II band compared with the 11-kb Bgl II band.

Deletion of the P450c21A pseudogene in haplotype II is confirmed further by probing Taq I-digested DNA with the 476-bp Bam HI-Kpn I 5' fragment of C4 cDNA. Such Southern blots show absence of the 7.0-kb Taq I fragment but retention of the 6.4-kb fragment, consistent with deletion of the C4A gene. Haplotype II was found just as frequently or more so among clinically normal chromosomes (14.3\% of our 84 normal chromosomes, see below), as it was among chromo- 


\section{RESTRICTION PATTERNS OF P450c21 GENES IN CAH PATIENTS}

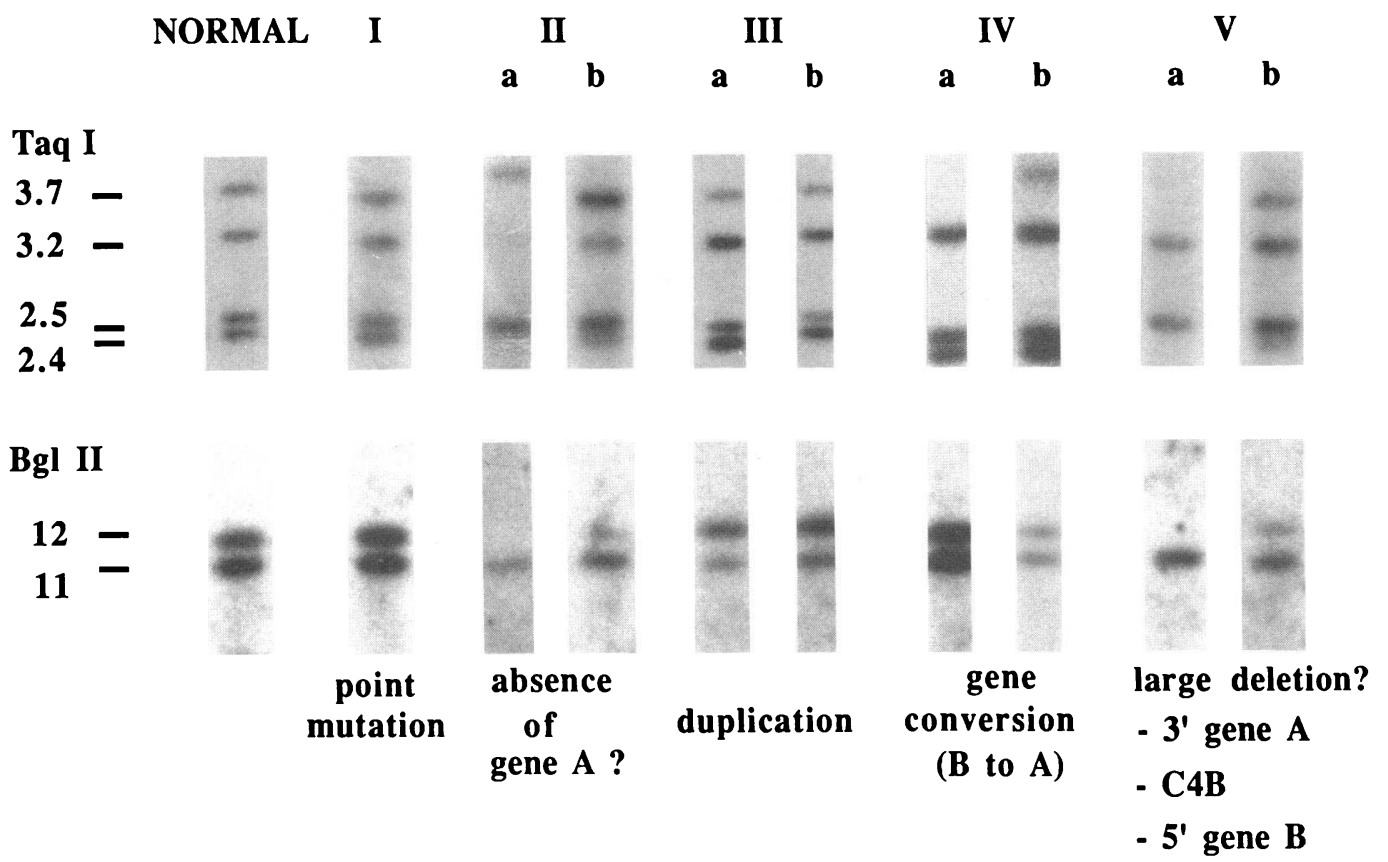

Figure 2. Southern transfer blots typical of the five restriction endonuclease haplotypes. Blots of DNA digested with Taq I are shown above; those digested with $\mathrm{Bgl}$ II are shown below. The sizes of the fragments (in kilobases) are shown at the left. Normal, DNA from a normal person; the four Taq I bands are of equal intensity and the two Bgl II bands are of equal intensity. Haplotype I is identical to the normal pattern but comes from a patient with severe saltwasting $\mathrm{CAH}$. For haplotypes II-V, lane $a$ shows a patient homozygous for that haplotype and lane $b$ shows a patient heterozygous with a chromosome bearing haplotype I. Hap-

lotype II, deletion of the P450c21 A pseudogene. In the Ila homozygote, the 3.2- and 2.4-kb Taq I fragments, and the 12-kb Bgl II fragment, all characteristic of the P450c21A pseudogene, are absent. In the I/II heterozygote shown in lane II $b$, these bands appear in diminished intensity because only the type I chromosome contributes them to the pattern. Haplotype III, duplication of the P450c21A pseudogene. The 3.2- and 2.4-kb Taq I bands and the 12-kb Bgl II bands are darker because there is an extra P450c21 A pseudogene on each chromosome. In the IIIb heterozygote this difference in intensity is less, about the 3:2 ratio expected; however, Southern blots are inherently non-quantitative and thus assignment of a patient as type IIIb must be done in conjunction with HLA and complement data and family studies. Haplotype IV, gene conversion. In the IVa homozygote, the 3.7-kb Taq I band is absent but the other five bands remain. In the IVb heterozygote, the 3.7-kb band is fainter than the 3.2-kb band because only the heterozygous chromosome bearing haplotype I contributes this band. Haplotype $\mathrm{V}$, gene deletion. The 3.7- and 2.4-kb Taq I bands and 12-kb Bgl II band are absent, indicating a large deletion of $\sim 30 \mathrm{~kb}$ resulting in a single hybrid $\mathrm{P} 450 \mathrm{c} 21 \mathrm{~A} / \mathrm{B}$ gene. In the $\mathrm{Vb}$ heterozygote the intensities of these bands are diminished.

somes associated with $\mathrm{CAH}$. Deletion of the P450c21A pseudogene thus does not cause CAH but is simply associated with point mutations in the P450c21B gene causing some cases of $\mathrm{CAH}$

CAH haplotype III. Haplotype III homozygotes have increased autoradiographic intensities of the 3.2- and 2.4-kb Taq I fragments, but the 3.7- and 2.5-kb Taq I fragments are still present. They also have both the 11- and 12-kb Bgl II bands, but the autoradiographic intensity of the $12-\mathrm{kb}$ bands is increased. This haplotype, which represents $6.9 \%$ (8 of 116) of the chromosomes in our study, probably arises from a duplication of the P450c21A pseudogene. A patient heterozygous for this haplotype and haplotype I will have a 2:3 ratio of the 3.7- and 3.2-kb Taq I fragments. Because of the inherently nonquantitative nature of Southern blotting, these may be mistaken for a 2:2 ratio (normal or haplotype I) or a 1:2 ratio (haplotypes IV and V). As with haplotype II, haplotype III may be found in normal persons, indicating that the duplicated P450c21A pseudogene is merely associated with CAH but does not cause it. Therefore, patients having $\mathrm{CAH}$ and haplotype III must have point mutations in their grossly intact P450c21B genes. The incidence of point mutation causing CAH in our study thus is the sum of the incidences of haplotypes I, II, and III ( 88 of $116,75.9 \%$ ) (Table II).

$C A H$ haplotypes $I V$ and $V$. Haplotypes IV and V are the ones of greatest interest, representing gene conversion and gene deletion, respectively. Among our study of 116 chromosomes, haplotypes IV and V each represent $11.2 \%$ of the total (13 of 116). In the homozygous state, both haplotypes completely lack the 3.7-kb Taq I band normally associated with the functional P450c21B gene, a pattern generally interpreted as diagnostic of gene deletion. However, haplotype IV retains both the 2.4- and 2.5-kb Taq I bands seen only with the genomic probe, whereas haplotype $\mathrm{V}$ lacks the $2.4-\mathrm{kb}$ band. Homozygotes for haplotype IV retain both the 11- and 12-kb Bgl II fragments yielding equal autoradiographic intensities, whereas homozygotes for haplotype V lack the 12-kb Bgl II fragment normally associated with the $\mathrm{P} 450 \mathrm{c} 21 \mathrm{~A}$ pseudogene. In haplotype IV both $\mathrm{P} 450 \mathrm{c} 21$ genes are present, but there is a change in the structure of the $5^{\prime}$ end of the P450c21B gene, converting it to the structure of a P450c21A gene. Thus, a chromosome bearing haplotype IV has two $3.2-\mathrm{kb}$ Taq I fragments and no 3.7-kb Taq I fragments, but most other restriction endonuclease recognition sites are the same as in normal DNA, and both the C4A and C4B genes are retained and function normally (Table $\mathrm{V}$ ).

Haplotype $V$ represents a physical loss of $\sim 30 \mathrm{~kb}$ of DNA, probably from an unequal crossover event. Disappearance of the 2.4-kb Taq I band normally associated with the P450c21 A pseudogene, rather than of the $2.5-\mathrm{kb}$ Taq I band associated with the deleted P450c21 B gene, and of the 12-kb Bgl II fragment (A pseudogene) rather than the 11-kb Bgl II fragment (B 
Table II. Frequency of Five Restriction Pattern Haplotypes in 57 CAH Families

\begin{tabular}{|c|c|c|c|c|c|c|}
\hline Haplotype & Clinical form & Homozygous & Heterozygous & $\begin{array}{l}\text { Haplotypes } \\
(n=116)\end{array}$ & Frequency & $\begin{array}{l}\text { Unaffected haplotypes } \\
\qquad(n=84)\end{array}$ \\
\hline & & & & & & $\%$ \\
\hline \multicolumn{7}{|l|}{ I } \\
\hline \multirow[t]{3}{*}{ Point mutation } & SW & 18 & 17 & 53 & & \\
\hline & SV & 6 & 3 & 15 & 65.6 & 84.5 \\
\hline & $\mathrm{NC}$ & 3 & 3 & 8 & & \\
\hline \multicolumn{7}{|l|}{ II } \\
\hline $\begin{array}{l}\text { Absence of A pseudogene } \\
\text { III }\end{array}$ & SW & 1 & 2 & 4 & 3.4 & 14.3 \\
\hline \multirow[t]{3}{*}{ Duplication of A pseudogene } & SW & - & 2 & 2 & & \\
\hline & SV & 1 & 1 & 3 & 6.9 & 1.2 \\
\hline & NC & - & 3 & 3 & & \\
\hline \multicolumn{7}{|l|}{ IV } \\
\hline \multirow[t]{2}{*}{ Gene conversion } & SW & 2 & 7 & 11 & 11.2 & 0.0 \\
\hline & SV & - & 2 & 2 & & \\
\hline \multicolumn{7}{|l|}{ V } \\
\hline \multirow[t]{2}{*}{ Large deletion } & SW & 4 & 5 & 12 & 11.2 & 0.0 \\
\hline & SV & - & 1 & 1 & & \\
\hline \multirow[t]{2}{*}{ Others } & SW & - & 1 & 1 & 1.7 & 0.0 \\
\hline & SV & - & 1 & 1 & & \\
\hline
\end{tabular}

The numbers under "homozygous" or "heterozygous" refer to numbers of patients. The numbers under "haplotype" refer to the number of affected chromosomes (total, 116). The unaffected haplotypes are from 84 normal chromosomes borne by obligate heterozygotes.

Table III. Gene Frequencies (Percentages) of the C4A and $C 4 B$ Alleles

\begin{tabular}{|c|c|c|c|c|c|c|}
\hline \multirow[b]{2}{*}{ Alleles } & \multicolumn{3}{|c|}{ Unaffected chromosomes } & \multicolumn{2}{|c|}{$\begin{array}{c}\text { CAH } \\
\text { chromosomes }\end{array}$} & \multirow[b]{2}{*}{$\begin{array}{c}\text { Chi square } \\
\text { test }\end{array}$} \\
\hline & $\begin{array}{c}\mathrm{I} \\
(n=38) \\
(a)\end{array}$ & $\begin{array}{c}\text { II } \\
(n=10) \\
(b)\end{array}$ & $\begin{array}{l}\text { Total } \\
(n=48) \\
(c)\end{array}$ & $\begin{array}{c}\mathrm{I} \\
(n=50) \\
(d)\end{array}$ & $\begin{array}{c}\text { Total } \\
(n=91) \\
(e)\end{array}$ & \\
\hline \multicolumn{7}{|l|}{ C4A locus } \\
\hline $\mathrm{AQ0}$ & 10.5 & 60.0 & 20.8 & 14.0 & 9.9 & $a$ vs. $b^{*}$ \\
\hline Al & 2.6 & - & 2.1 & - & - & \\
\hline $\mathrm{A} 2$ & - & - & - & 6.0 & 7.7 & $c$ vs. $e^{\ddagger}$ \\
\hline A3 & 65.8 & 30.0 & 58.3 & 64.0 & 49.4 & \\
\hline A4 & 13.1 & 10.0 & 12.5 & 10.0 & 5.4 & \\
\hline A6 & 5.3 & - & 4.2 & - & - & \\
\hline A91 & - & - & - & - & 6.7 & \\
\hline $\begin{array}{c}\text { A dupli } \\
\text { tion }\end{array}$ & 2.6 & - & 2.1 & 2.0 & 3.3 & \\
\hline \multicolumn{7}{|l|}{ C4B locus } \\
\hline $\mathrm{BQ} 0$ & 18.4 & 40.0 & 22.9 & 6.0 & 18.7 & \\
\hline B1 & 55.3 & 40.0 & 52.1 & 68.0 & 47.3 & \\
\hline B2 & 10.5 & 10.0 & 10.4 & 10.0 & 6.6 & \\
\hline B3 & 7.9 & 10.0 & 8.3 & 10.0 & 5.5 & \\
\hline B6 & 5.3 & - & 4.2 & 2.0 & - & \\
\hline B1B2 & 2.6 & - & 2.1 & - & 7.7 & \\
\hline
\end{tabular}

I and II correspond to restriction pattern haplotypes shown on Fig. 2: Column $c$ labeled "total" is the sum of columns $a$ and $b ; n$, number of chromosomes studied. Significance was tested with a Chi square test. $P$ values are: ${ }^{*}<0.001,{ }^{\ddagger} 0.05$. For C4AQ0, $c$ vs. $e$ is: $>0.05$ and $<0.1$. gene), is not inconsistent and helps to define the limits of the DNA deletion. The deletion in haplotype $\mathrm{V}$ probably extends from exon 3 of the P450c21A pseudogene to the homologous site in the P450c21 B gene, thus deleting the 2.4-kb Taq I fragment but retaining the $2.5-\mathrm{kb}$ Taq I fragment. The $5^{\prime}$ deletion site in the P450c21A gene and the $3^{\prime}$ deletion site in the P450c21B gene must correspond very closely, because the electrophoretic mobility of the resulting Taq I-digested hybrid product is indistinguishable from a normal 3.2-kb Taq I band associated with the P450c21 A gene. Similarly, the $11-\mathrm{kb}$ Bgl II fragment seen in haplotype $\mathrm{V}$ is a hybrid consisting of the upstream $\left(5^{\prime}\right)$ portion of the 12-kb P450c21 A pseudogene and the downstream $\left(3^{\prime}\right)$ portion corresponding to the P450c21B gene (Fig. 1). Deletion of the P450c21 B gene in haplotype $\mathrm{V}$ is confirmed by probing Taq I-digested genomic DNA with the C4 cDNA, showing absence of either the $6.0 \mathrm{~kb}$ or $5.4 \mathrm{~kb} \mathrm{C} 4$ gene fragments (Fig. 3).

2 of the 116 chromosomes examined could not be classified as bearing one of the five haplotypes discussed above. These two chromosomes bore Taq I patterns compatible with haplotype IV but had $\mathrm{Bgl}$ II patterns compatible with haplotypes III and V, respectively. These two chromosomes show that the five haplotypes discussed here account for most but not all chromosomes bearing $\mathrm{CAH}$. Chromosomes bearing uninterpretable and seemingly contradictory restriction endonuclease patterns have been described in a series of families with salt-losing CAH (25).

DNA haplotypes of unaffected chromosomes. We assigned different Taq I restriction patterns to 84 unaffected chromosomes from obligate CAH heterozygotes. Among these, 71 $(84.5 \%)$ had normal Taq I restriction patterns, but $12(14.3 \%)$ had haplotype II and 1 had haplotype III (Table II). Deletion of 
Table IV. Unaffected Haplotypes with a Detectable Alteration of P450c21 Genes

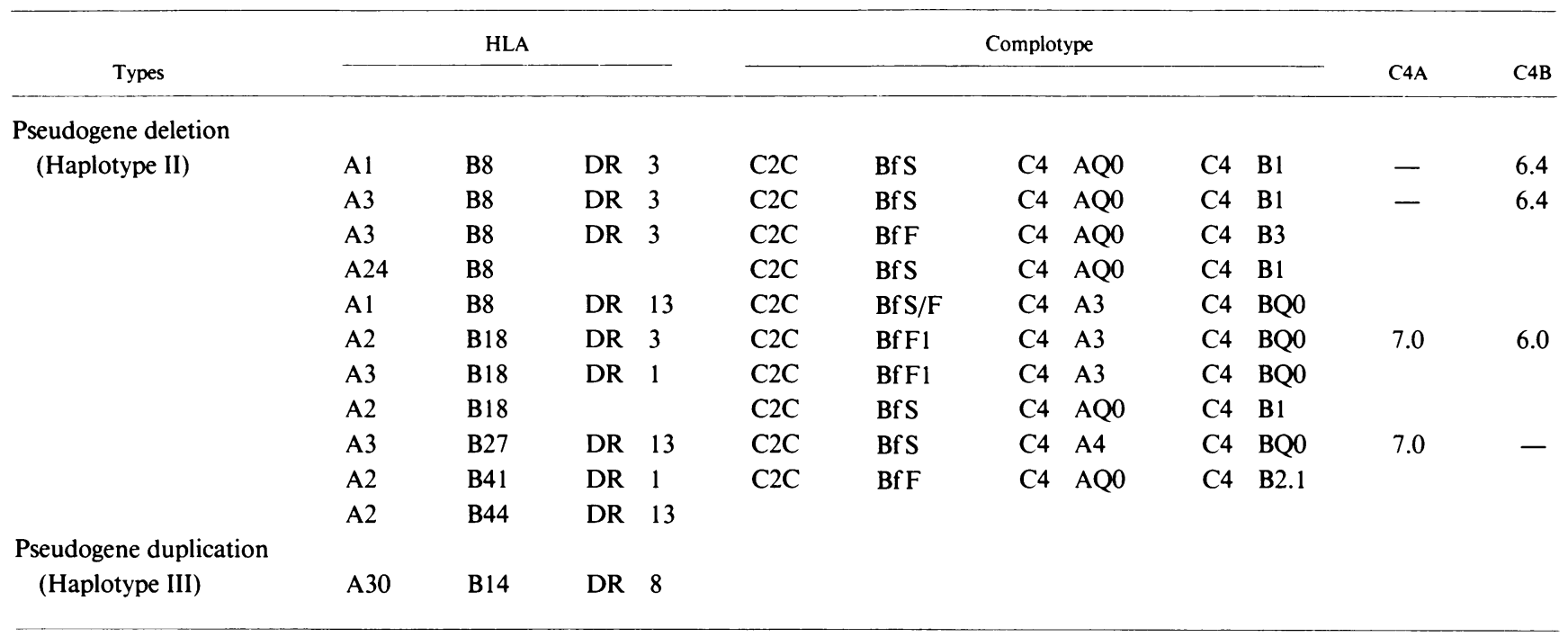

Column C4A represents the sizes (in kilobases) of fragments that hybridized to the $5^{\prime} \mathrm{C} 4$ probe: $7.0 \mathrm{~kb}(\mathrm{C} 4 \mathrm{~A}), 6.0 \mathrm{~kb}$ (long C4B), $6.4 \mathrm{~kb}(\mathrm{C} 4 \mathrm{~B}$ with a deletion of $\mathrm{C} 4 \mathrm{~A}$ ).

the P450c21A pseudogene has been reported in some normal subjects $(17,18)$; finding haplotype II on normal chromosomes confirms that the 2.4-kb Taq I fragment segregates with the P450c21A pseudogene.

Associated deletions of the $\mathrm{C} 4 \mathrm{~A}$ and $\mathrm{C} 4 \mathrm{~B}$ genes were indicated by HLA typing for 11 and complement typing for 10 of these 12 normal chromosomes bearing haplotype II (Table IV). Five of these carried HLA-B8, which is associated with deletion of the P450c21A pseudogene (18-20), and complement typing showed six $\mathrm{C} 4 \mathrm{AQ} 0$ and four $\mathrm{C} 4 \mathrm{~A} 3, \mathrm{BQ} 0$ alleles.

To confirm apparent deletions of the C4A or C4B genes, four normal chromosomes were probed with $\mathrm{C} 4 \mathrm{cDNA}$ (Table IV and Fig. 3). Absence of a 7.0-kb Taq I band and presence of a 6.4-kb Taq I band are characteristic of deletion of the C4A gene (20). This pattern segregates with the complotype C4AQ0 and confirms deletion of the C4A gene and the P450c21A pseudogene (Fig. 3, family C, haplotype $b$ ). By contrast, presence of the $7.0-\mathrm{kb}$ band and absence of the C4B Taq I fragments $(6.0$ or $5.4 \mathrm{~kb})$ is characteristic of deletion of the $C 4 B$ gene. This pattern segregates with the complotype $C 4 A 4, B Q 0$ and confirms a deletion encompassing the $\mathrm{C} 4 \mathrm{~B}$ gene and the P450c21 A pseudogene (Fig. 3, family D, haplotype $c$ ).

These studies of unaffected chromosomes indicate that three Taq I patterns are compatible with normal 21-hydroxylase activity: pattern I (normal); pattern II (deletion of the P450c21A pseudogene); and pattern III (duplication of the P450c21A pseudogene). As discussed above, CAH-bearing chromosomes having haplotypes II or III are thus presumed to have point mutations in their $\mathrm{P} 450 \mathrm{c} 21 \mathrm{~B}$ genes.

Correlation between restriction endonuclease haplotypes and clinical form of $C A H$. Table II shows the distribution of $\mathrm{SW}, \mathrm{SV}$, and NC CAH among the five haplotypes. Homozygotes for Type I (point mutation) may have any form of CAH. This indicates there are many different point mutations causing this disease, some of which eliminate essentially all enzymatic activity of P450c21, while others affect the enzyme only slightly. Because DNA haplotyping by restriction endonuclease digestion cannot distinguish among various different point mutations, persons who are homozygous for Type I may be compound heterozygotes of two different point mutations. The one homozygous patient available with haplotype II had SW CAH and the one homozygote with haplotype III had SV $\mathrm{CAH}$. These patients further indicate that a disorder in the $\mathrm{P} 450 \mathrm{c} 21 \mathrm{~B}$ gene is causing the $\mathrm{CAH}$; it is doubtful the presence or absence of the P450c21A pseudogene could have a phenotypic manifestation. All homozygotes for haplotypes IV and $\mathrm{V}$ had SW $\mathrm{CAH}$, as would be expected if the functional $\mathrm{P} 450 \mathrm{c} 21 \mathrm{~B}$ gene were deleted or converted to a nonfunctional gene.

Correlation of restriction endonuclease haplotypes with $H L A$ and complement haplotypes. Linkage disequilibrium between certain HLA types and CAH (34-36) is also found in our study, indicating that our patient population is typical and representative (Table I). Complement typing should be even more informative because the $\mathrm{C} 4$ loci are so closely linked to the P450c21 genes; however, the great technical difficulty in performing $\mathrm{C} 4$ typing prevented its unambiguous determination in eight families. C4AQ0 was closely associated with haplotype II (deletion of the P450c21A pseudogene), but its overall incidence was lower on chromosomes bearing $\mathrm{CAH}$ alleles (9.9\%) than on normal chromosomes $(20.8 \%)$ (Table III). By contrast, $\mathrm{C} 4 \mathrm{BQ} 0$ was found with equal frequency among normal and CAH-bearing chromosomes, but all chromosomes bearing a P450c21 B gene deletion also bore C4BQ0 (12 of 12), consistent with a $30-\mathrm{kb}$ deletion encompassing the $\mathrm{C} 4 \mathrm{~B}$ gene. One chromosome bearing haplotype IV also bore C4BQ0 and $\mathrm{C} 4 \mathrm{~A} 2 \mathrm{~A} 2$, suggesting that the $\mathrm{C} 4 \mathrm{~B}$ gene was converted to a $\mathrm{C} 4 \mathrm{~A}$ in conjunction with conversion of the $\mathrm{P} 450 \mathrm{c} 21 \mathrm{~B}$ gene to a P450c21A pseudogene. Similar events have been described on other chromosomes encoding $\mathrm{CAH}(37,38)$, but all our other chromosomes bearing haplotype IV had markers for both $\mathrm{C} 4$ genes.

Some extended supratypes are clearly linked to $\mathrm{CAH}$ (Table V). Among the 12 chromosomes bearing haplotype $\mathrm{V}$, 6 carry HLA-A3,-B47,-DR7,C2C,BfF,C4A91,C4BQ0. Although HLA-B47 is strongly associated with P450c21B gene 

A
B
C
D
E $\mathbf{F}$

PROBE h 21cDNA

$3.7-$

$3.2-$
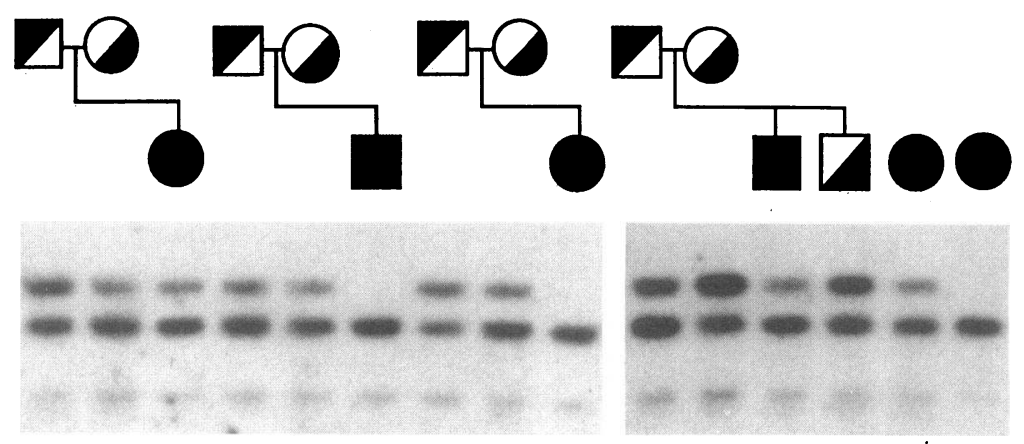

m 21gDNA

$3.7-$
$3.2-$
$2.5=$
$2.4=$

h C4gDNA

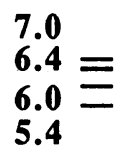

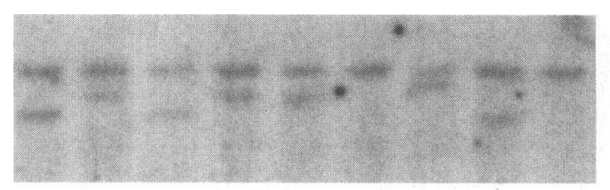

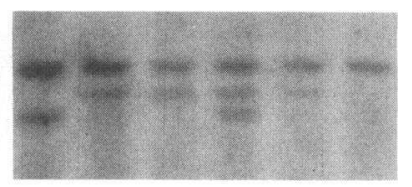

$\mathrm{a} / \mathrm{b} \mathrm{c} / \mathrm{d}$ a/d a/b c/d a/d a/b c/d a/d a/b c/d a/d b/d a/d a/d

Figure 3. Studies of pedigrees bearing CAH haplotype V. $\mathbf{v}$ and $\bullet$, males and females, respectively; solid symbols and half-open/half-solid symbols represent homozygous affected individuals (21-hydroxylase deficiency) and heterozygotes, respectively. The haplotype for each individual is indicated at the bottom of the figure: $a$ and $d$ designate chromosomes bearing $\mathrm{CAH} ; b$ and $c$ represent unaffected chromosomes. The affected individuals in families B, C and F are homozygous for haplotype V. The extended haplotype, the sizes (in kilobases) of the fragments hybridizing to the 5' C4 cDNA probe (hC4DNA) and the restriction pattern haplotype defined in Fig. 2 are shown below. The P450c21 probes used are human P450c21 cDNA (h21cDNA), and mouse P450c21 genomic DNA (m21gDNA). The validity of the mouse genomic probing strategy is shown by finding the same pattern of 3.7- and 3.2-kb Taq I fragments with this probe and with the human cDNA probe. The complement and HLA types of the chromosomes, the sizes of their C4A and C4B genes digested with Taq I and their Southern blotting haplotypes are as follows:

\begin{tabular}{|c|c|c|c|c|c|c|c|c|c|c|c|c|}
\hline \multicolumn{2}{|c|}{ Family } & \multicolumn{3}{|c|}{ HLA haplotype } & \multicolumn{5}{|c|}{ Complotype } & \multirow{2}{*}{$\frac{\mathrm{C} 4 \mathrm{~A}}{7.0}$} & \multirow{2}{*}{$\begin{array}{l}\text { C4B } \\
5.4\end{array}$} & \multirow{2}{*}{$\begin{array}{c}\text { Haplotype } \\
\text { I }\end{array}$} \\
\hline A & $\mathbf{a}$ & A24 & B58 & DR2/7 & $\mathrm{C} 2 \mathrm{C}$ & BfF & $\mathrm{C} 4$ & $\mathrm{AQ} 0$ & B1 & & & \\
\hline & b & A3 & B35 & DR2/7 & $\mathrm{C} 2 \mathrm{C}$ & BfS & $\mathrm{C} 4$ & A4 & B2 & 7.0 & 5.4 & I \\
\hline & c & A29 & B55 & DR2/7 & $\mathrm{C} 2 \mathrm{C}$ & BfS & $\mathrm{C} 4$ & A3 & B1 & 7.0 & 6.0 & I \\
\hline & d & $\mathrm{A} 3$ & B47 & $\mathrm{DR} 2 / 7$ & $\mathrm{C} 2 \mathrm{C}$ & BfF & $\mathrm{C} 4$ & A91 & $\mathrm{BQ} 0$ & 7.0 & - & V \\
\hline \multirow[t]{4}{*}{ B } & $\mathbf{a}$ & A26 & B5 & DR1 & $\mathrm{C} 2 \mathrm{C}$ & BfS & $\mathrm{C} 4$ & A3 & BQ0 & 7.0 & - & V \\
\hline & b & A24 & B35 & DR 11 & $\mathrm{C} 2 \mathrm{C}$ & BfS & $\mathrm{C} 4$ & A3 & B1 & 7.0 & 6.0 & I \\
\hline & $\mathrm{c}$ & A29 & B44 & DR 11 & $\mathrm{C} 2 \mathrm{C}$ & BfS & $\mathrm{C} 4$ & A3 & B1 & 7.0 & 6.0 & I \\
\hline & $d$ & A3 & B47 & DR7 & $\mathrm{C} 2 \mathrm{C}$ & $\mathrm{BfF}$ & $\mathrm{C} 4$ & A91 & BQ0 & 7.0 & - & V \\
\hline \multirow[t]{4}{*}{$\mathrm{C}$} & $\mathbf{a}$ & A3 & B47 & DR7 & $\mathrm{C} 2 \mathrm{C}$ & BfF & $\mathrm{C} 4$ & A91 & BQ0 & 7.0 & - & V \\
\hline & $\mathrm{b}$ & Al & B8 & DR3 & $\mathrm{C} 2 \mathrm{C}$ & BfS & $\mathrm{C} 4$ & $\mathrm{AQO}$ & B1 & - & 6.4 & II \\
\hline & c & A3 & B35 & DR7 & $\mathrm{C} 2 \mathrm{C}$ & $\mathrm{BfS}$ & C4 & AQ0 & B1 & 7.0 & 5.4 & I \\
\hline & $d$ & A3 & B35 & DRI & $\mathrm{C} 2 \mathrm{C}$ & $\mathrm{BfF}$ & $\mathrm{C} 4$ & A3 & BQO & 7.0 & - & V \\
\hline \multirow[t]{4}{*}{ D } & $\mathbf{a}$ & A3 & B47 & DR7 & $\mathrm{C} 2 \mathrm{C}$ & $\mathrm{BfF}$ & $\mathrm{C} 4$ & A91 & BQ0 & 7.0 & - & $\mathbf{V}$ \\
\hline & b & A2 & B18 & DR7 & $\mathrm{C} 2 \mathrm{C}$ & Bf S & $\mathrm{C} 4$ & A3 & B1 & 7.0 & 5.4 & I \\
\hline & c & A3 & B27 & DR 13 & $\mathrm{C} 2 \mathrm{C}$ & Bf S & $\mathrm{C} 4$ & A4 & BQ0 & 7.0 & - & II \\
\hline & d & A30 & B49 & DR 13 & $\mathrm{C} 2 \mathrm{C}$ & BfS & $\mathrm{C} 4$ & A3 & B1 & 7.0 & 6.0 & I \\
\hline \multirow[t]{2}{*}{$E$} & $\mathbf{a}$ & A3 & B47 & DR7 & $\mathrm{C} 2 \mathrm{C}$ & $\mathrm{BfF}$ & $\mathrm{C} 4$ & A91 & BQ0 & 7.0 & - & V \\
\hline & d & A32 & B 12 & DR5 & & & & & & 7.0 & 6.0 & I \\
\hline \multirow[t]{2}{*}{$\mathrm{F}$} & $\mathbf{a}$ & Al & B41 & DR2 & $\mathrm{C} 2 \mathrm{C}$ & BFS & $\mathrm{C} 4$ & A3 & BQ0 & 7.0 & - & V \\
\hline & $\mathrm{d}$ & Al1 & B7 & DR 1 & $\mathrm{C} 2 \mathrm{C}$ & BFS & $\mathrm{C} 4$ & A3 & BQ0 & 7.0 & - & $\mathbf{V}$ \\
\hline
\end{tabular}


Table V. CAH Haplotypes with a Detectable Alteration of P450c21 Genes

\begin{tabular}{|c|c|c|c|c|c|c|c|c|c|c|c|c|c|}
\hline Types & & \multicolumn{4}{|c|}{ HLA } & \multicolumn{6}{|c|}{ Complotype } & $\mathrm{C} 4 \mathrm{~A}$ & $\mathrm{C} 4 \mathrm{~B}$ \\
\hline Pseudogene deletion & $\mathbf{a}$ & A3 & B35 & DR & 3 & $\mathrm{C} 2 \mathrm{C}$ & Bf S & $\mathrm{C} 4$ & AQ0 & $\mathrm{C} 4$ & B1 & - & 6.4 \\
\hline \multirow[t]{2}{*}{ (Haplotype II) } & b & Al & B8 & DR & 3 & $\mathrm{C} 2 \mathrm{C}$ & $\mathrm{BfS}$ & $\mathrm{C} 4$ & AQ0 & $\mathrm{C} 4$ & B1 & - & 6.4 \\
\hline & c & A 11 & B35 & DR & 1 & $\mathrm{C} 2 \mathrm{C}$ & $\mathrm{BfF}$ & $\mathrm{C} 4$ & A3 & $\mathrm{C} 4$ & BQ0 & & \\
\hline \multirow{4}{*}{$\begin{array}{l}\text { Pseudogene duplication } \\
\text { (Haplotype III) }\end{array}$} & $a(4)$ & A28 & B14 & & & $\mathrm{C} 2 \mathrm{C}$ & BfS & $\mathrm{C} 4$ & $\mathrm{~A} 2$ & $\mathrm{C} 4$ & B1B2 & & \\
\hline & $b(2)$ & A33 & B14 & DR & 1 & $\mathrm{C} 2 \mathrm{C}$ & Bf S & $\mathrm{C} 4$ & $\mathrm{~A} 2$ & $\mathrm{C} 4$ & B1B2 & & \\
\hline & $\mathrm{c}^{*}$ & Al & B17 & DR & 1 & $\mathrm{C} 2 \mathrm{C}$ & Bf S & $\mathrm{C} 4$ & $\mathrm{~A} 2$ & $\mathrm{C} 4$ & B1B2 & & \\
\hline & $d$ & A29 & B44 & DR & 8 & $\mathrm{C} 2 \mathrm{C}$ & $\mathrm{BfF}$ & $\mathrm{C} 4$ & $\mathrm{~A} 3 \mathrm{~A} 1$ & $\mathrm{C} 4$ & B1 & & \\
\hline \multirow{11}{*}{$\begin{array}{l}\text { Gene conversion } \\
\text { (Haplotype IV) }\end{array}$} & $\mathrm{a}(2)$ & A31 & B14 & DR & 7 & $\mathrm{C} 2 \mathrm{C}$ & $\mathrm{BfS}$ & $\mathrm{C} 4$ & A3 & $\mathrm{C} 4$ & B1 & & \\
\hline & $b(2)$ & $\mathrm{A} 1$ & B27 & DR & 5 & $\mathrm{C} 2 \mathrm{C}$ & & & & & & & \\
\hline & $\mathrm{c}$ & A26 & B27 & DR & 1 & $\mathrm{C} 2 \mathrm{C}$ & BfS & $\mathrm{C} 4$ & A3 & $\mathrm{C} 4$ & B1 & & \\
\hline & $\mathrm{d}$ & A24 & B62 & DR & 4 & $\mathrm{C} 2 \mathrm{C}$ & $\mathrm{BfF}$ & $\mathrm{C} 4$ & $\mathrm{~A} 2 \mathrm{~A} 2$ & $\mathrm{C} 4$ & BQ0 & & \\
\hline & e & A2 & B37 & DR & 13 & $\mathrm{C} 2 \mathrm{C}$ & $\mathrm{BfF}$ & $\mathrm{C} 4$ & $\mathrm{~A} 3$ & $\mathrm{C} 4$ & B1 & & \\
\hline & f & A 32 & B44 & DR & 11 & $\mathrm{C} 2 \mathrm{C}$ & $\mathrm{BfS}$ & $\mathrm{C} 4$ & A3 & $\mathrm{C} 4$ & B1 & & \\
\hline & $\mathbf{g}$ & A 32 & B44 & & & $\mathrm{C} 2 \mathrm{C}$ & $\mathrm{BfS}$ & $\mathrm{C} 4$ & A2 & $\mathrm{C} 4$ & B2 & & \\
\hline & h & Al & B35 & DR & 7 & $\mathrm{C} 2 \mathrm{C}$ & & & & & & & \\
\hline & $\mathrm{i}$ & A2 & B51 & DR & 2 & $\mathrm{C} 2 \mathrm{C}$ & $\mathrm{BfS}$ & $\mathrm{C} 4$ & A3 & $\mathrm{C} 4$ & B1 & 7.0 & 6.0 \\
\hline & $\mathrm{j}$ & Al & B57 & DR & 1 & $\mathrm{C} 2 \mathrm{C}$ & & & & & & & \\
\hline & $\mathrm{k}$ & $\mathrm{A} 3$ & B7 & DR & 8 & $\mathrm{C} 2 \mathrm{C}$ & & & & & & & \\
\hline \multirow{8}{*}{$\begin{array}{l}\text { Deletion } \\
\text { (Haplotype V) }\end{array}$} & $a(6)$ & $\mathrm{A} 3$ & B47 & DR & 7 & $\mathrm{C} 2 \mathrm{C}$ & $\mathrm{BfF}$ & $\mathrm{C} 4$ & A91 & $\mathrm{C} 4$ & BQ0 & 7.0 & - \\
\hline & $\mathrm{b}$ & A26 & B5 & DR & 1 & $\mathrm{C} 2 \mathrm{C}$ & $\mathrm{BfS}$ & $\mathrm{C} 4$ & $\mathrm{~A} 3$ & $\mathrm{C} 4$ & BQ0 & 7.0 & - \\
\hline & c & A3 & B35 & DR & 1 & $\mathrm{C} 2 \mathrm{C}$ & Bf S & $\mathrm{C} 4$ & $\mathrm{~A} 3$ & $\mathrm{C} 4$ & $\mathrm{BQ} 0$ & 7.0 & - \\
\hline & d & $\mathrm{Al}$ & B41 & $\mathrm{DR}$ & 2 & $\mathrm{C} 2 \mathrm{C}$ & BFS & $\mathrm{C} 4$ & A3 & $\mathrm{C} 4$ & BQ0 & 7.0 & - \\
\hline & $\mathrm{e}$ & A11 & B7 & DR & 1 & $\mathrm{C} 2 \mathrm{C}$ & BFS & $\mathrm{C} 4$ & A3 & $\mathrm{C} 4$ & $\mathrm{BQ0}$ & 7.0 & - \\
\hline & f & A26 & B62 & $\mathrm{DR}$ & 8 & & & $\mathrm{C} 4$ & A3 & $\mathrm{C} 4$ & BQ0 & & \\
\hline & $\mathrm{g}$ & $\mathrm{A} 2$ & B40 & & & & & & & & & 7.0 & - \\
\hline & $\mathrm{h}$ & $\mathrm{A} 28 / 32$ & B18/35 & DR & $13 / 7$ & & & $\mathrm{C} 4$ & A3/A3 & $\mathrm{C} 4$ & $\mathrm{~B} 1 / \mathrm{BQ} 0$ & & \\
\hline \multirow[t]{2}{*}{ Undeterminable } & $\mathbf{a}$ & A30 & B27 & DR & 1 & $\mathrm{C} 2 \mathrm{C}$ & $\mathrm{BfS}$ & $\mathrm{C} 4$ & $\mathrm{~A} 3$ & $\mathrm{C} 4$ & $\mathrm{BQ} 0$ & 7.0 & 6.0 \\
\hline & $\mathrm{b}$ & A29 & B27 & $\mathrm{DR}$ & 1 & $\mathrm{C} 2 \mathrm{C}$ & $\mathrm{BfS}$ & $\mathrm{C} 4$ & A 13 & $\mathrm{C} 4$ & BQO & & \\
\hline
\end{tabular}

c*: Recombination with HLA B14; a(4), number of same haplotype; and -, absence of bands.

deletions, we found two chromosomes bearing HLA-B47 and type I CAH haplotypes (P450c21B point mutations). These two chromosomes bore very different supratypes from the haplotype V chromosomes bearing HLA-B47: one was HLAA30,-B47,-DR2,C2C,BfS,C4A3,B1, and the other was HLAA3,-B47,-DR13. Nondeletion alleles bearing B47 have been reported in SW CAH $(25,26)$, and in an isolated normal population (39). A similar conservation of supratypes is seen in six of the eight chromosomes having haplotype III, which have either HLA-A28 or -A33 associated with -B14, BfS,C4A2, C4B1B2 (Table V). The latter supratype has a duplication of both the P450c21A pseudogene and the C4B locus, and is frequently found in patients with $\mathrm{NC} \mathrm{CAH}$. We have also found six other recombinations in addition to the gene rearrangements described above. These include three recombinations between HLA-A and -B and three between HLA-B and -DR (data not shown).

\section{Discussion}

We used Taq I and Bgl II digests to analyze DNA from 57 French families having one to three children with $\mathrm{CAH}$, and two affected parents, for a total of 68 patients. The distribution of clinical forms of $\mathrm{CAH}$ in our study of affected children is similar to that in other studies (17-22), but clearly different from a study of adults emphasizing NC CAH (35). The distribution of HLA-B types in our French Caucasian population does not differ from other studies (34-36), so our patient population is wholly typical. Our study differs from previous reports in the size of the population examined and the use of the genomic probe, which detects the DNA $3^{\prime}$ to the P450c21 genes. This unique probing strategy permitted us to assign 114 of $116 \mathrm{CAH}$-bearing chromosomes to five haplotypes. The remaining two chromosomes presented a confusing array of restriction endonuclease patterns. This is not wholly surprising, as Matteson et al. (25) have shown that the restriction endonuclease patterns found in some $\mathrm{CAH}$ patients can be inconsistent and inexplicable by the simple genetic models accounting for haplotypes $I-V$. Such restriction endonuclease patterns might arise from compound heterozygosity among haplotypes II-V and/or other, uncharacterized gene rearrangements.

Among the $116 \mathrm{CAH}$ chromosomes characterized, 76 (65.9\%) had haplotype I, indicating point mutations or other changes sufficiently small to be undetectable on Southern blots. Four chromosomes (3.4\%) bore haplotype II, which in- 
dicates deletion of the P450c21 A pseudogene and may; or may not, be associated with a deletion of either of the $\mathrm{C} 4$ genes encoding the fourth component of serum complement. Haplotype II is not specific for $\mathrm{CAH}$, because $14.2 \%$ of chromosomes not bearing $\mathrm{CAH}$ alleles carry haplotype II. Thus, the genetic lesion in $\mathrm{CAH}$ chromosomes bearing haplotype II must be an associated point mutation in the $\mathrm{P} 450 \mathrm{c} 21 \mathrm{~B}$ gene.

Eight chromosomes $(6.9 \%)$ bore a duplication of P450c21A pseudogene (haplotype III) and duplication of either C4A or C4B, in association with $\operatorname{HLA}-\mathrm{B} 14(21,35)$. The supratype HLA-A28/A33-B14 C4A2, B1B2 was frequently associated with P450c21A duplication (six of eight chromosomes). Although this supratype has been associated with NC $\mathrm{CAH}(21,35)$ and is found in 3 of our $11 \mathrm{NC}$ patients, our one patient homozygous for this supratype had SV CAH. Haplotype III thus shares a crucial characteristic with haplotype II: it can be found on unaffected chromosomes. Therefore, the lesion causing $\mathrm{CAH}$ on these chromosomes must be an associated point mutation in the $\mathrm{P} 450 \mathrm{c} 21 \mathrm{~B}$ gene, and the $\mathrm{CAH}$ is not directly caused by duplication of the P450c21A pseudogene. This hypothesis is strongly supported by recent sequencing data showing a point mutation in the $\mathrm{P} 450 \mathrm{c} 21 \mathrm{~B}$ gene of a patient homozygous for HLA-B14-DR 1 and duplication of the P450c21A pseudogene (40).

When applied to gene alterations associated with $\mathrm{CAH}$, the term gene conversion refers to a change in part or all of the P450c21B gene, converting part or all of its structure to a P450c21A pseudogene $(16,23-28,37)$. Gene conversion can be most easily conceptualized as resulting from two unequal crossover events, but many other mechanisms may also be involved (see reference 15 for review and references). Gene conversions in $\mathrm{CAH}$ have been documented by Southern blotting studies (23-27) and by DNA sequencing (9, 27, 41). Simple Taq I digests alone probed with P450c21 cDNA cannot distinguish gene conversion (haplotype IV) from gene deletion (haplotype V); hence, the relative incidence of these two classes of mutations has been unclear and somewhat controversial. The use of both Taq I and Bgl II digests in conjunction with a genomic probe detecting the Taq I fragments $3^{\prime}$ to the P450c21 genes now greatly simplifies this task. We found equal numbers of chromosomes bearing deletion or conversion, 13 of 116 or $11.2 \%$ for each lesion. Other studies report greatly varying relative incidences of these two lesions (24-28), presumably due to the small number of patients studied or to population differences, or both.

The available data now localize the region where the presumed gene conversion event(s) must occur. No reported examples of gene conversion modify the sizes of the 11- and $12-\mathrm{kb}$ Bgl II fragments or, in our study, of the $2.4-$ and $2.5-\mathrm{kb}$ Taq I fragments. These observations and the published sequencing data $(27,42)$ delineate the $3^{\prime}$ end of the conversion event as lying downstream from the 8-bp deletion in exon 3 and upstream from exon 4 of the P450c21 A pseudogene. Because $C 4 B$ protein is detected in seven of eight gene conversion haplotypes, the $5^{\prime}$ limit probably lies downstream $\left(3^{\prime}\right)$ from the C4B gene. Similarly, the limits of the gene deletion in chromosomes bearing haplotype $\mathrm{V}$ should include the $3^{\prime}$ end of the P450c21A pseudogene to the $5^{\prime}$ end of the P450c21B gene, in a 30-kb deletion proc̉ucing a hybrid, nonfunctional P450c21 A/ B pseudogene giving 3.2- and 2.5-kb Taq I fragments.

Our studies thus show that most chromosomes encoding $\mathrm{CAH}$ carry point mutations of the P450c21B gene. These may be found on three haplotypes, here termed haplotypes I, II, and III, which together encompass $75.9 \%$ of the chromosomes in our study. Determination of the genetic lesions in these chromosomes requires cloning and sequencing the affected DNA. Specific amplification of affected sequences by polymerase chain reaction technology (43) is not effective, because the $98 \%$ sequence identity of the P450c21 A and B genes prohibits suitably specific priming (Y. Morel and W. L. Miller, unpublished observations). Of the remaining CAH chromosomes, equal numbers (11.2\%) bear gene deletions (haplotype $\mathrm{V}$ ) and gene conversions (haplotype IV), while a small number $(1.7 \%)$ still escape characterization by our procedures. Our procedures, using a genomic probe extending $3^{\prime}$ to the P450c21A and $B$ genes, now permit simple and accurate characterization of $>98 \%$ of chromosomes encoding $\mathrm{CAH}$. We propose that Taq I digests alone are sufficient for accurate genetic diagnosis in $\sim 98 \%$ of cases if family studies are done and if the blots are examined with a genomic probe extending $3^{\prime}$ to the P450c21 genes (e.g., the 3.1-kb Eco RI/Bam HI fragment of the human genes); examination of these blots with a $5^{\prime} \mathrm{C} 4 \mathrm{cDNA}$ probe can provide useful confirmation.

\section{Acknowledgments}

We thank Danielle Frank and Michelle Auvinet for technical assistance, and Carol Dahlstrom for typing the manuscript.

This work was supported by Institut National de la Santé et de la Recherche Medicale (INSERM) U34 and INSERM CJF 88-05, and by grants from the March of Dimes (6-396) and National Institutes of Health (NIH) (DK:37922) to W. L. Miller. Y. Morel is supported by grants from la Fondation pour la Recherche Medicale and the Philippe Foundation, and by NIH Fogarty International Fellowship TW03935.

\section{References}

1. Dupont, B., S. E. Oberfield, E. R. Smithwick, T. D. Lee, and L. S. Levine. 1977. Close genetic linkage between HLA and congenital adrenal hyperplasia (21-hydroxylase deficiency). Lancet. ii:13091312.

2. Miller, W. L., and L. S. Levine. 1987. Molecular and clinical advances in congenital adrenal hyperplasia. J. Pediatr. 111:1-17.

3. Miller, W. L. 1988. Molecular biology of steroid hormone synthesis. Endocr. Rev. 9:295-318.

4. Nebert, D. W., M. Adesnik, M. J. Coon, R. W. Estabrook, FR. J. Gonzalez, F. D. Guengerich, I. C. Gunsalus, E. F. Johnson, B. Kemper, W. Levin, I. R. Phillips, R. Sato, and M. R. Waterman. 1987. The P450 gene superfamily: recommended nomenclature. DNA (NY). $6: 1-11$.

5. Carroll, M. C., R. D. Campbell, and R. P. Porter. 1985. Mapping of steroid 21-hydroxylase genes adjacent to complement component C4 genes in HLA, the major histocompatibility complex in man. Proc. - Natl. Acad. Sci. USA. 82:521-525.

6. White, P. C., D. Grossberger, B. J. Onufér, D. D. Chaplin, M. I. New, B. Dupont, and J. L. Strominger. 1985. Two genes encoding steroid 21-hydroxylase are located near the genes encoding the fourth component of the complement in man. Proc. Natl. Acad. Sci. USA. 82:1089-1093.

7. Higashi, Y., H. Yoshioka, M. Yamane, O. Gotoh, and Y. FujiiKuriyama. 1986. Complete nucleotide sequence of two steroid 21-hydroxylase genes tandemly arranged in human chromosome: a pseudogene and a genuine gene. Proc. Natl. Acad. Sci. USA. 83:2841-2845.

8. White, P., M. I. New, and B. Dupont. 1986. Structure of the human steroid 21-hydroxylase genes. Proc. Natl. Acad. Sci. USA. 83:5111-5115.

9. Rodrigues, N. R., I. Dunham, C. Y. Yu, M. C. Carroll, R. R. Porter, and R. D. Campbell. 1987. Molecular characterization of the HLA-linked steroid 21-hydroxylase B gene from an individual with 
congenital adrenal hyperplasia. EMBO (Eur. Mol. Biol. Organ.) J. 6:1653-1661.

10. Dunham, I., C. A. Sargent, J. Trowsdale, and R. D. Campbell. 1987. Molecular mapping of the human major histocompatibility complex by pulsed-field gel electrophoresis. Proc. Natl. Acad. Sci. USA. 84:7237-7241.

11. Chung, B., K. J. Matteson, and W. L. Miller. 1986. Structure of a bovine gene for P450c21 (steroid 21-hydroxylase) defines a novel cytochrome P450 gene family. Proc. Natl. Acad. Sci. USA. 83:42434247.

12. Amor, M., M. Tosi, C. Duponchel, M. Steinmetz, and T. Meo. 1985. Liver cDNA probes disclose two cytochrome P450 genes duplicated in tandem with the complement $\mathrm{C} 4$ loci of the mouse $\mathrm{H}-2 \mathrm{~S}$ region. Proc. Natl. Acad. Sci. USA. 82:4453-4457.

13. Skow, L. C., J. E. Womack, J. M. Petresh, and W. L. Miller. 1988. Synteny mapping of the genes for steroid 21-hydroxylase, alpha-A-crystallin, and class I bovine leukocyte antigen in cattle. $D N A$ (NY). 7:143-149.

14. Hood, L., J. H. Campbell, and S. C. R. Elgin. 1975. The organization expression and evolution of antibody genes and other multigene families. Annu. Rev. Genet. 9:305-353.

15. Liebhaber, S. A., M. Goossens, and Y. W. Kan. 1981. Homology and concerted evolution of the $\alpha-1$ and $\alpha-2$ loci of human $\alpha$-globin. Nature (Lond.). 290:26-29.

16. Miller, W. L. 1988. Gene conversions, deletions, and polymorphisms in congenital adrenal hyperplasia. Am. J. Hum. Genet. 42:4-7.

17. White, P. C., M. I. New, and B. Dupont. 1984. HLA-linked congenital adrenal hyperplasia results from a defective gene encoding a cytochrome P450 specific for steroid 21-hydroxylation. Proc. Natl. Acad. Sci. USA. 81:7505-7509.

18. Carroll, M. C., A. Pasldottir, K. T. Belt, and R. R. Porter. 1985. Deletion of complement $\mathrm{C} 4$ and steroid 21-hydroxylase genes in the HLA class III region. EMBO (Eur. Mol. Biol. Organ.) J. 4:2547-2552.

19. Garlepp, M. J., A. N. Wilton, R. L. Dawkins, and P. C. White. 1986. Rearrangement of 21-hydroxylase genes in disease-associated MHC supratypes. Immunogenetics. 23:100-105.

20. Schneider, P. M., M. C. Carroll, C. A. Alper, C. Rittner, A. S. Whitehead, E. J. Yunis, and H. R. Colton. 1986. Polymorphism of the human complement $\mathrm{C} 4$ and steroid 21-hydroxylase genes. J. Clin. Invest. 78:650-657.

21. Werkmeister, J. W., M. I. New, B. Dupont, and P. C. White. 1986. Frequent deletion and duplication of the steroid 21-hydroxylase genes. Am. J. Hum. Genet. 39:461-469.

22. Rumsby, G., M. C. Carroll, R. R. Porter, D. B. Grant, and M. Hjelm. 1986. Deletion of the steroid 21-hydroxylase and complement $\mathrm{C} 4$ genes in congenital adrenal hyperplasia. J. Med. Genet. 23:204209.

23. Donohoue, P. A., C. Van Dop, R. H. McLean, P. C. White, N. Jospe, and C. J. Migeon. 1986. Gene conversion in salt-losing congenital adrenal hyperplasia with absent complement C4B protein. J. Clin. Endocrinol. \& Metab. 62:995-1002.

24. Jospe, N., P. A. Donohoue, C. Van Dop, R. H. McLean, W. Bias, and C. J. Migeon. 1987. Prevalence of polymorphic 21-hydroxylase gene (CA21 HB) mutations in salt-losing congenital adrenal hyperplasia. Biochem. Biophys. Res. Commun. 142:798-804.

25. Matteson, K. J., J. A. Phillips III, W. L. Miller, B. Chung, P. J. Orlando, H. Frisch, A. Ferrandez, and I. M. Burr. 1987. P450XXI (steroid 21-hydroxylase) gene deletions are not found in family studies of congenital hyperplasia. Proc. Natl. Acad. Sci. USA. 84:5858-5862.

26. Higashi, Y., A. Tanae, H. Inoue, and Y. Fujii-Kuriyama. 1988. Evidence for frequent gene conversions in the steroid 21-hydroxylase (P-450c21) gene: implications for steroid 21-hydroxylase deficiency. Am. J. Hum. Genet. 42:17-25.

27. Harada, F., A. Kimura, T. Iwanaga, K. Shimozawa, J. Yata, and T. Sasazuki. 1987. Gene conversion-like events cause steroid 21- hydroxylase deficiency in congenital adrenal hyperplasia. Proc. Natl. Acad. Sci. USA. 84:8091-8094.

28. White, P. C., A. Vitek, B. Dupont, and M. I. New. 1988. Characterization of frequent deletions causing steroid 21-hydroxylase deficiency. Proc. Natl. Acad. Sci. USA. 85:4436-4440.

29. Betuel, H., L. Geburher, J. Lambert, A. C. Freidel, and A. Sarre. 1980. A possible new HLA-DR allele. Hum. Immunol. 8:227237.

30. Forest, M. G., H. Betuel, P. Couillin, and A. Boue. 1981. Prenatal diagnosis of congenital adrenal hyperplasia (CAH) due to 21-hydroxylase deficiency by steroid analysis in the amniotic fluid of mid-pregnancy: comparison with HLA typing in 17 pregnancies at risk for CAH. Prenatal Diagn. 1:197-207.

31. Uring-Lambert, B., C. M. Giles, J. Goetz, M. M. Tongio, S. Mayer, and G. Hauptmann. 1984. C4 haplotypes with duplicated C4A or C4B: frequency and associations with $\mathrm{Bf}, \mathrm{C} 2$ and HLA-A,B,C,DR alleles with special reference to the duplication C4B1B2. In Histocompatibility Testing. E. D. Albert, M. P. Baur, and W. R. Mayr, editors. Springer-Verlag, Berlin. 604-608.

32. O'Neill, G. J., C. W. Neri, G. Hauptmann, K. Suzuki, and H. Matsumoto. 1986. Monoclonal antibodies reveal further polymorphism of human C4. Immunobiology. 173:466. (Abstr. 34.)

33. Belt, K. T., M. C. Carroll, and R. R. Porter. 1984. The structural basis of the multiple forms of human complement component C4. Cell. 36:907-914.

34. Holler, W., S. Scholz, D. Knorr, F. Bidlingmaier, E. Keller, and D. A. Ekkehard. 1985. Genetic differences between the salt-wasting, simple virilizing and nonclassical types of congenital adrenal hyperplasia. J. Clin. Endocrinol. \& Metab. 60:757-763.

35. Mornet, E., P. Couillin, F. Kutten, M. C. Raux, P. C. White, D. Cohen, A. Boue, and J. Dausset. 1986. Associations between restriction fragment length polymorphisms detected with a probe for human 21-hydroxylase (21-OH) and two clinical forms of 21-OH deficiency. Hum. Genet. 74:402-408.

36. Dupont, B., R. Virdis, A. J. Lerner, C. Nelson, M. S. Pollack, and M. I. New. 1984. Distinct HLA-B antigen associations for saltwasting and simple virilizing forms of congenital adrenal hyperplasia due to 21-hydroxylase deficiency. In Histocompatibility Testing. E. D. Albert, M. P. Baur, and W. R. Mayr, editors. Springer-Verlag, Berlin. 660 .

37. Palsdottir, A., A. Arnason, R. Fossdal, and O. Jensson. 1987. Gene organization of haplotypes expressing two different $\mathrm{C} 4 \mathrm{~A}$ allotypes. Hum. Genet. 76:220-224.

38. Giles, C. M., B. Uring-Lambert, W. Boksch, M. Braun, J. Goetz, R. Neumann, G. Mauff, G. Hauptmann. 1987. The study of a French family with two duplicated C4A haplotypes. Hum. Genet. 77:359-365.

39. Donohoue, P. A., C. Van Dop, C. J. Migeon, R. H. McLean, and W. B. Bias. 1987. Coupling of HLA-A3,Cw6,Bw47,DR7 and a normal CA21 HB steroid 21-hydroxylase gene in the old order Amish. J. Clin. Endocrinol. \& Metab. 65:980-986.

40. Speiser, P. W., M. I. New, and P. C. White. 1988. Molecular genetic analysis of nonclassical steroid 21-hydroxylase deficiency associated with HLA-B14,DR1. N. Engl. J. Med. 319:19-23.

41. Amor, M., K. L. Parker, H. Globerman, M. I. New, and P. C. White. 1988. Mutation in the CYP21B gene (Ile-172 $\rightarrow$ Asn) causes steroid 21-hydroxylase deficiency. Proc. Natl. Acad. Sci. USA. 85:1600-1604.

42. Jospe, N., P. A. Donohoue, C. Van Dop, and C. J. Migeon. 1988. Crossing-over sites within the 21-hydroxylase (CYP21) genes causing salt-losing congenital adrenal hyperplasia (CAH). Pediatr. Res. 23:279A. (Abstr.)

43. Wong, C., C. E. Dowling, R. K. Saiki, R. G. Higuchi, H. A. Erlich, and H. H. Kazazian. 1987. Direct genomic sequencing of amplified single copy DNA: rapid characterization of unknown $\beta$-thalassemia mutations. Nature (Lond.). 330:384-386. 